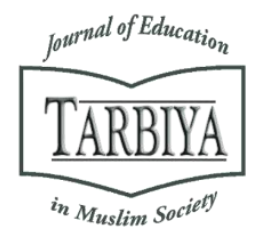

Available online at TARBIYA: Journal of Education in Muslim Society Website:

http://journal.uinjkt.ac.id/index.php/tarbiya

TARBIYA: Journal of Education in Muslim Society, 5(2), 2018, 155-165

\title{
INTERCULTURAL COMMUNICATIVE LANGUAGE TEACHING IN CHINA: HIGHLIGHT OR ADDENDUM?
}

\author{
Qun Wang ${ }^{1}$, Syihabuddin ${ }^{2}$, Yeti Mulyati ${ }^{2}$, Vismaia S. Damaianti ${ }^{2}$ \\ ${ }^{1}$ Xi' an International Studies University, X'ian, China \\ ${ }^{2}$ Indonesia University of Education, Bandung, Indonesia \\ E-mail: semiya123@hotmail.com; syihabuddin@upi.edu
}

Received: $6^{\text {th }}$ October 2018; Revised: $26^{\text {th }}$ November 2018; Accepted: $28^{\text {th }}$ December 2018

\section{Abstract}

International students were frequently reported of culture shock issues when entering a new cultural environment. Cultural knowledge was often treated as an addendum which focused on learning facts about the target country. This article demonstrated culture shock that experienced by 7 international students, and also reviewed intercultural communicative language teaching (ICLT) in Indonesian language classrooms practiced by 6 language practitioners from 3 different universities in China. Using findings that emerged from a series of one-to-one interviews, the research explored practitioners' current perspective of ICLT and how these understandings influenced their practices, including teaching materials, methods, and activities. The researcher discussed the possible causes of the status quo of ICLT in China, and went on to put forward suggestions that ICLT should be promoted in foreign language teaching as a successful mediator of intercultural dimension.

Keywords: ICLT; ICC; culture shock; religion-wise issues

\section{Abstrak}

Mahasiswa internasional sering dilaporkan tentang masalah kejutan budaya ketika memasuki lingkungan budaya baru. Pengetahuan budaya sering diperlakukan sebagai tambahan yang berfokus pada mempelajari fakta tentang negara sasaran. Artikel ini menunjukkan kejutan budaya yang dialami oleh 7 siswa internasional, dan juga mengulas pengajaran bahasa komunikatif antarbudaya (ICLT) di ruang kelas bahasa Indonesia yang dipraktikkan oleh 6 praktisi bahasa dari 3 universitas berbeda di Tiongkok. Menggunakan temuan yang muncul dari serangkaian wawancara satu-ke-satu, penelitian mengeksplorasi perspektif praktisi saat ini tentang ICLT dan bagaimana pemahaman ini mempengaruhi praktik mereka, termasuk bahan ajar, metode, dan kegiatan. Peneliti membahas kemungkinan penyebab status quo ICLT di Cina, dan kemudian mengajukan saran bahwa ICLT harus dipromosikan dalam pengajaran bahasa asing sebagai mediator sukses dimensi lintas budaya.

Kata kunci: ICLT; ICC; kejutan budaya; masalah agama-bijaksana

How to Cite :, Wang, Q., Syihabuddin., Mulyati, Y., Damaianti, V. S. (2018). Intercultural Communicative Language Teaching in China: Highlight or Addendum?. TARBIYA: Journal of Education in Muslim Society, 5(2), 155-165. doi:10.15408/tjems.v5i2.9732.

Permalink/DOI: http://dx.doi.org/10.15408/tjems.v5i2.9732

TARBIYA: Journal of Education in Muslim Society, P-ISSN: 2356-1416, e-ISSN: 2442-9848

This is an open access article under CC-BY-SA license (https://creativecommons.org/licenses/by-sa/4.0/) 


\section{Introduction}

International students were frequently reported of culture shock issues when entering a new cultural environment. Culture shock is a well-known term used to define the initial experiences of immersion in an unfamiliar culture (Lombard, 2014). It was first used by the anthropologist Kalervo Oberg in 1954 and was defined as "the anxiety which results from losing all familiar signs and symbols of social intercourse". In recent years, researchers have proposed more findings on culture shock. Amongst them, Guinapa (1998) pointed out that culture shock is "the physical and emotional discomfort one suffers when coming to live in another country or a place different from the place of origin. This term expresses the lack of direction, the feeling of not knowing what to do or how to do things in a new environment, and not knowing what is appropriate or inappropriate.”

It is important to note that international students do not study language exclusively. They also attend social and cultural activities in the foreign community. Language and culture are inseparable. Learning a foreign language well means not only mastering the pronunciation, grammar, words and idioms, but also means learning the ways in which their language reflects the ideas, customs, and behaviour of their society, and also to understand their "language of the mind" (Huang, 2014). In order to be wellprepared of culture shock issues, students need to learn about the behavioural style and beliefs of local people, and also acquire the social skills of the host culture (Rinehart, 2002; Yang, Webster \& Prosser, 2011). This requires that students should be equipped with intercultural communicative competence (ICC) when entering a new cultural environment.

It is seen that the concept of ICC is variously defined by different scholars, which is generally described as the knowledge, motivation, and skills to interact with members of different cultures (Chen, 1989; Wiseman, 2003). In this research, ICC can be understood as the ability which enables one to effectively and appropriately interact in a language other than one's native language with others from different linguistic and cultural backgrounds. It consists of language competence (linguistic, sociolinguistic, and discourse competence) and intercultural competence (attitudes, knowledge, skills, and awareness) that help one to be able to successfully integrate in a multicultural society (adapted from Bennett \& Bennett, 2004; Byram, 1997; Fantini, 2001; Sinicrope et al., 2007). As to second language learners, in order to succeed internationally, one needs to acquire ICC to typically adapt a new foreign culture. This requires not only sufficient linguistic and language skills and knowledge about the host culture, but also a willingness to understand host-culture members (Barker, 2016).

The above illustration has generated ICC improvement as cultural preparation before students initiating overseas study. Intercultural communicative language teaching (ICLT) has begun to emerge in response to the limitations of general language teaching $(\mathrm{Gu}, 2016)$. ICLT emphasizes that language is taught not merely for transfer of information, but for the assertion, negotiation, and construction and maintenance of individual and group identities (Corbett, 2003). The ultimate goal of ICLT is to help learners to become intercultural speakers with ICC who can interact effectively and appropriately with others from different cultures (Tran \& Duong, 2018). ICLT has been widely promoted in Europe, America, and Australia through a series of initiatives (e.g. Byram \& Zarate, 1997; CARLA, 1993-2006; Cloonan, Spencer, \& Saunders,2005; Liddicoat, Papademetre, Scarino, \& Kohler, 2003; Prechtl $\&$ Lund, 2007). It has recently been introduced 
to China by a number of Chinese scholars, who call for a paradigm shift from CLT to ICLT in Chinese foreign language teaching (e.g. Song, 2008; Zhang, 2007a).

Brown (1994) argues that, in practice, language and culture are often separated in the foreign language classroom, and culture becomes little more than an addendum which focuses on "learning facts about the target country". Cultural knowledge in a foreign language learning classroom has often been interpreted as the teaching of "a series of selected facts, customs, and traditions" that learners need to understand and appreciate in order to become "culturally competent" (Flinders Humanities Research Centre, 2005). When cultural knowledge is conceptualised as an important component of the ICLT in foreign language learning experience, it becomes something that can be treated as distinct from, and an adjunct to, developing learners' communicative proficiency, as language knowledge and cultural knowledge were two equally supportive elements of unhindered communication, which is the very representation of ICC (East, 2012).

\section{Indonesian language teaching in China}

The Indonesian language made its first entry into China with the establishment of the Department of Indonesian Language at Peking University in 1949. Recent years, with the growth of bilateral cooperation under the "Belt and Road Initiative", more and more universities and colleges in China have begun to set up Indonesian language programs. Till the year of 2016, in the Chinese mainland, there are a total amount of 15 educational institutions that have an Indonesian language program. Unlike English programs, Indonesian language programs only exist at several major foreign language studies universities in China or at colleges in border cities in southern China.
Based on guidelines applied in several Indonesian language programs in China, Indonesian language learners are required to use the Indonesian language as a means of communication to transfer thoughts, cultures, and values in order to create good relationships between China and Indonesia. Students also are required to attend overseas scholarship programs sponsored by China Scholarship Council (CSC), Indonesia Dharmasiswa Program, or Indonesia Kemitraan Negara Berkembang (KNB) Scholarship. This has encouraged Chinese students to take one academic year, or even longer, to study language in Indonesia. Besides, increasing overseas recruitment has become the target of most universities (Ryan \& Carroll, 2005). Many Chinese students have planned to work in Indonesia after graduating from college. However, previous studies have found that most Chinese Indonesian-language students were suffering from culture shock when studying in Indonesia, and lacking preparation of ICC in mother country had directly resulted in the mentioned problem (Wang, Syhabuddin, Mulyati, \& Damaianti, 2018).

\section{The Study}

The researcher self is a lecturer in a university in China who teaches the Indonesian language to Chinese students. Thus, the research context was set in Indonesian language classroom in order to explore the ICLT situation in China.

To ascertain the ICLT in foreign language classrooms in China, the research sought to investigate the following questions:

RQ1: Were there any culture shock issues when Chinese Indonesian-language students were studying in Indonesia?

RQ2: How do Chinese practitioners understand the relationship between cultural knowledge and language teaching? 
RQ3: What are the present teaching method adopted, activities conducted and textbooks used to enhance students' ICC in language classroom in China?

In addition to that, the researcher went on to explore the possible causes and solutions of the status quo of ICLT in China.

\section{Methods}

To address the research questions, a qualitative approach, more specifically qualitative case study, was used for seeking the status quo of ICLT in a context of Indonesian language classroom in China. Qualitative approaches provide detailed descriptions of socially constructed realities, which make them appropriate for studying complex processes that play out in specific settings (Casmir, 1999; Creswell, 2007). In this research, data were collected through one-on-one interviews, during which the researcher explored students' personal experience on culture shock, and the practitioners' emic perspectives on ICLT in China and the teaching techniques and materials applied through teaching activities. 7 Chinese Indonesian-language students and 6 Chinese Indonesian-language practitioners took part in the research.

\section{Research techniques}

The researcher conducted one-on-one interviews with participants to examine research questions. The interviews took place respectively in the middle of an academic semester (October 2017). The interview questions for students were all open-ended questions to explore participants' factual experience and authentic opinions. Meanwhile, the interview questions for practitioners were developed based on ICC Composing Factors and ICC Influencing Factors $(\mathrm{Gu}, 2016)$ and aforementioned findings on students' intercultural communicative behaviours. The researcher used a semistructured schedule with both objective items to identify participants' understanding of ICLT and also open-ended questions to investigate the status quo of ICLT in foreign teaching classroom in China. In the actual interviews, the mentioned schedule was used as a guideline in case the participants had more comprehensive and useful information that could be applied in the research. All interviews were done in Mandarin Chinese and recorded by the researcher, a friend and colleague had a rapport with all participants, fluent in English and Indonesian language. Therefore, participants' real sentiments could be elicited to the maximum extent. The interview transcripts and notes were all translated into English by the researcher as well.

\section{Participants}

The first group of participants in this research were 7 Chinese Indonesian-language students who had just finished their first semester in a university in Indonesia. The second group of participants in this research were 6 Chinese Indonesian-language practitioners from 3 universities in China ageing from 27 to 44 . Five of them were females and one was male. They all self-reported that their teaching experience were over 2 years, and the longest one was 12 years.

\section{Data analysis}

Qualitative approach was adopted to explore and understand the meaning individuals ascribe to a social or human problem (Creswell, 2007). Data from the first session of interviews collected to identify the fact of culture shock issues that took place among international students. Data from the second session of interviews were collected through the use of the previously described techniques were classified into two categories: teaching activities that related to ICC 
enhancement in language teaching and perspectives of ICLT in China. The analysis was conducted in several steps. First, the entire dataset was read for a comprehensive review. Next, the key data was grouped under similar concepts then formed into categories. Finally, participants' manifestation in interviews was clustered, categorized, and interpreted with attention in view of intercultural communicative competence in order to triangulate and guide the research.

\section{Results and Discussion}

\section{Religion-wise Culture Shock Issue as One Example}

Based on the enormous difference in between religion-wise situations in between China and Indonesia, the researcher also interviewed the students as participants about their experiences in religion-wise culture shock issues that took place when learning and living in Indonesia.

Firstly, customs and routine. In general, there has been a fatwa which forbids free mixing between men and women, especially when alone. One male participant reported, "When living in a boarding house in Indonesia, you need to pay attention to the 'no girls' rule, which is 'no boys' rule for girls. However, I reckon that we are all adults here and we can be responsible for what we do." Other male participants reported more culture shock issues on differences of daily. They were accustomed to hanging out till late night in pubs or coffee shops, but found out that their bedtime routines did not suit with Indonesian friends'. One participant said, "I was once hanging out with some Indonesian Muslim friends. It turns out they could not stay up till 00:00 a.m. because they need to get up at 03:00 a.m. for prayers. They also had curfew schedules in their boarding houses." Likewise, some participants reported that Friday was their least favorite day in a week because it was the day for "shalat Jum'ah" (a congregational prayer that Muslims hold every Friday), and errands were often postponed on Friday.

Secondly, rituals. What catches the researcher's eye was that all participants reported the "disturbance" from "azaan", the calling out for prayers from a loudspeaker in a mosque. One participant illustrated her anxiety when hearing the "azaan" for the first time, "It was a loud and endless sound. I guess it wasn't Indonesian language, but some kind of mantra. I was aroused from my sleep at 04:00 a.m.. Can you believe it? I might sound a bit selfish, but I would appreciate if they turning down the volume of the loudspeaker." Another participant echoed, 'You could hear 'azaan' coming from every corner within your earshot on the eve of Corban Festival. I was frightened because I thought it was a religious demonstration. After I found out that it would last for a whole night, I just grinned and bore it. I never knew this 'azaan' chanting and have never heard of it before when learning Indonesian language in China."

Thirdly, outfits. Aside to the inconvenience in daily life, all three female participants expressed their confusion about female Muslim's outfits. One participant argued that: " $I$ understand the Muslim dressing code, yet there are numerous female Muslims who don't wear a 'hijab' or a veil. That means that those who scrupulously abide by the religious code have an alternative, a prettier alternative. I would've chosen fashion over everything." Another participant was shocked by the "special sportswear for Muslims", "I saw Muslim girls in swimsuits covering head to ankle. I thought it was diving suit, but, no, it was a Muslim swimwear. I wanted to ask them how they feel in contrast to people wearing bikinis, but I was afraid to offend them." 
Fourthly, food and drinks. Religion-wise, particularly, all seven participants expressed their yearning towards pork and beer since there was seldom access to purchasing them. In addition to their own experience, participants complemented some views on Indonesian people's food habits. One participant said, "Some of my friends fasted on Friday. They didn't eat nor drink till 18:00 p.m.. I admired their persistence and strong beliefs. On the other hand, I doubted whether if the fasting could do harm to their metabolism system."

Lastly, communication. The collected data showed that the religion-wise culture impact was bidirectional, which means the local Indonesian Muslims were also confused by Chinese participants' religious situation. Nevertheless, their confusion had brought more troubles to the participants. One participant reported, "I was often asked about my religion. At first, I explained that China is a socialist and communist country and I have no religion, but this answer only made Indonesian people more confused and astonished. I guess religion does mean a lot to them. Sadly, I can't get it because I'm an atheist."

To sum up the data collected from indepth interviews in the first session, all participants have encountered religion-wise from culture shock. Even though they were excited to study in Indonesia, at times, confusion, uncertainty, anxiety, stress and fright haunted their excitement. Religion is merely one factor of the whole cultural system. With the fact being there has been plenty of culture shock issue in religion-wise communication, cultural knowledge should not be treated as a discrete factor apart from language learning, and ICLT should be promptly developed and applied in Chinese language teaching.

\section{Culture Teaching in Class}

The second part of interview focused on the present curriculum, teaching method adopted, and textbooks used to enhance students' ICC in language classroom in China.

Data indicated that "Indonesian Culture" as a subject was enlisted in the course arrangement of all 3 universities. Nevertheless, this solo subject only took up 2 to 3 credits of all 250 credits, which accounted for $1 \%$ of the whole curriculum. Also it should be noted that there were other subjects related to Indonesian culture, such as "Tourism in Indonesia" and "Indonesian Literature History", even though those subjects didn't make up much of a significant proportion in credits. When asked whether there was a plan or development on curriculum that could enhance the teaching focus culture-wise, practitioners responded negatively. For example, Practitioner 1 noted that, "The curriculum was like a faculty 'heirloom'. It was amended sometimes, but the basic structure was still there." Practitioner 2 consented by adding that, "Cultural knowledge should be learnt well in a specific language environment, I mean, in Indonesia, not in here. It's too vague and sometimes abstract."

In terms of teaching method, all 6 practitioners reported that they adopted expository method in teaching activities. The practitioners described the method as the teacher presented information with little interaction taking place between the teachers and the students. When asked the activities conducted in class, Practitioner 2, 4, 5 and 6 answered that it was mostly a one-direction lecture in class without overt interaction. Practitioner 1 and 3 responded that they conducted "question and answer" games to inspire students' opinions on origins and development of Indonesian culture. All practitioners stressed the importance of using Microsoft Power Point slides because it could 
stimulate students' interest by using "colourful" teaching media.

Aside from the data on general teaching activities, there was a consensus on textbook among 6 practitioners, which was "Introduction to Indonesian Culture" published by World Book Press in China. The book was written by several Chinese experts on Indonesian culture in Mandarin. The book was divided into 9 chapters, including cultural and geographical environment, cultural development and evolution, substantial culture, folk beliefs, religious culture, traditional arts, manners and customs, festivals, and film and screen culture.

It can be seen from the research data that faculties of Indonesian Language in China has created a system of their own since establishment. Most of the practitioners were reluctant to modify what they had at present, thus the current mode of curriculum, teaching method and activities, and textbooks. The current situation lacked interaction in between students and teachers, which overtly neglected students' participation in learning a foreign host culture. In the meantime, there has not been a specific subject that could combine both intercultural competence and pragmatics at the same time, which is exactly what the students need when living in another country.

Besides, the researcher would like to point out that no practitioner had mentioned the term "intercultural communication competence" in the interview. Even though they all recognized the mentioned term, they had not considered ICC as one vital factor in improving culture-wise subjects, let alone in language learning.

\section{Culture as an Addendum to Language Teaching}

Interviews revealed that all 6 practitioners regarded culture as an addendum to language teaching, which means that culture was hardly a main part of the instructional objectives.

Most of the practitioners argued that the language study should always come first because it was the hard-and-fast rule for a languagemajored graduates to master the target language skills. For instance, Practitioner 1 noted that, "It was no doubt that every practitioner understands the definition of 'cultural knowledge' and the global trend of 'learning culture and language at the same time'. However, this society calls for students with better pragmatic skills rather than students who are fluent in a foreign culture."

Another reason why the researcher illustrated cultural knowledge as an addendum was because several practitioners saw cultural knowledge as a discrete factor apart from language learning. For example, Practitioner 2 argued that, "Sometimes when students saw a piece of news on a traditional communal feast in Java and they kept wondering about the details. Of course, I would be more than happier to introduce all the culture phenomena hidden behind the scene. But, that is it. That is culture, and that is interesting. What has it to do with language? Except when you recite it in Indonesian language...but then it's all about language again. So, they don't necessarily need to be interwoven."

Practitioner 2's reaction to the relationship between language and culture was therefore essentially information-driven and ethnocentric, whereby the second culture evaluated on a factual basis alongside students' mother culture and, in comparison, interpreted as "other" in a way that made it "interesting".

In addition to that, Practitioner 5 expressed that potentially the current curriculum and instructional objectives made language learning a priority, even though she sincerely wanted to introduce more cultural knowledge to students during language learning, “It's disappointing 
that I always run out of time in language teaching activities. I try to do as much as I can, such as send students videos of Indonesian festivals, and assign them tasks to look for words related to the festivals. But I have no time to do interaction, feedback or assessment. They haven't recited the vocabulary on textbooks yet."

Interview data show that treating culture as an addendum was because, to a large extent, the cultural knowledge was separated from language learning. In these cases, the ICC could hardly be improved in second language acquisition process.

The researcher traced the mentioned conditions and made a detailed inquiry on what the practitioners teach as cultural knowledge. It was put forward that practitioners were turning to more experiential ways of introducing cultural knowledge with the objective of enhancing students' motivation and enjoyment during language learning. Two common foci were food and festivals. According to Practitioner 1, students in her class even named the class chat room after a tropical fruit in Indonesia. Practitioner 3 explained, "Students liked to ask me about my overseas study experience in Indonesia. They were curious about the culinary culture. They were also intrigued by all kinds of religious festivals, traditional costumes, and parades in Indonesia."

Practitioner 6 once invited the Indonesian guest teacher to teach students how to make bakso (Indonesian meatballs). He reported that, "You always learn faster when being emerged in a specific environment. That's why I motivated students and our Indonesian teacher to work together so that they could share more in a lively practice. It's a shame that we didn't have enough time for activities like that."

Moreover, the researcher has also found out a severe problem that Chinese practitioners tend to take culture shock issues for granted. For example, when talking about most international students had suffered culture shock, Practitioner 3 reported that, "It was not that bad as people rumoured. When in Rome, do the Romans do. The psychological issues rarely happen, at least not to my students." To add another example, Practitioner 6 described culture shock effects as something "dramatic" and "temporary".

To sum up, although more experiential in nature, and thereby arguably providing enhanced opportunity for intercultural reflection, there was still no evidence in the aforementioned examples of integration with language. In addition to that, due to strict educational scheme enacted by Ministry of Education of the People's Republic of China, there left little room in structural modification of curriculum. Last but no least, culture shock issues should never be neglected when treating international students.

\section{Language as a Mediator of Culture: Starting from a Textbook}

Brown's (1994) argument reveals that language and culture are tightly interwoven such that separation of the two diminishes the significance of either. Engagement with a more integrated role for cultural knowledge was leading practitioners to interweave language and culture. This brings to the second part of interviews which focused practitioners' perspectives of ICLT in China. This article has explored practitioners' understandings about cultural knowledge, and how these understandings influenced their practices. They regarded exploring factual knowledge about the target culture as an important, as well as interesting and motivating, component of language learning. A number were beginning to provide opportunities for students to engage with different cultural practices through language. For the practitioners, however, cultural knowledge focused primarily on facts (Flinders Humanities Research Centre, 2005; Sehlaoui, 
2001). Beyond that, they had troubles in adjusting course content to timetable.

These findings suggest that, in terms of classroom practice of Indonesian language teaching in China, with their hands tied in redesigning curriculum, the most feasible plan is to develop a language learning textbook related to cultural knowledge as soon as possible. Thereby the researcher advised that a preconceived design of a textbook could be designed to help students to learn both language and culture of a host country at the same time. The textbook design should present a wholesome Indonesian cultural system which places a particular emphasis on pragmatics in tangible daily routine. It is anticipated that the textbook should be designed along with multimedia that included images, audios, and video clips of daily conversation and cultural phenomena. It is also advised to provide teachers' manuals and specific syllabus according to the contents. More importantly, the comparison between mother culture and foreign culture will be struck as the heart of textbook contents (e. g. the things a Chinese student should or should not be doing when visiting a mosque in Indonesia), in order to move towards interculturality and to alleviate culture shock issues.

\section{Conclusion}

Bearing in mind that ICC has become a core issue in second language acquisition for international students who were born and raised in an ear of globalization. The findings of this study suggest that language and culture are still separated in second language acquisition in China, and even though practitioners are aware of the importance of culture study, they can hardly interfere with curriculum structure. That being the case, there is still room for developing students' ICC ability in language learning process through ICLT, which is to develop textbooks and instructional multimedia that combine both language and culture in the contents. In addition to that, practitioners should also start to attach importance to culture shock issues of international students.

\section{References}

Barker. G. G. (2016). Cross-Cultural perspectives on intercultural communication competence, Journal of Intercultural Communication Research, 45(1), 13-30.

Brown, H. D. (1994). Principles of language learning and teaching ( $3^{\text {rd }}$ ed.). Englewood Cliffs, NJ: Prentice Hall Regents.

Bennett, J. M., \& Bennett, M. J. (2004). Developing intercultural sensitivity. In J. M. Bennett, M. J. Bennett, \& D. Landis (Eds.), Handbook of intercultural training ( $3^{\text {rd }}$ ed., pp. 147-165). Thousand Oaks, CA: Sage Publications.

Byram, M., \& Zarate, G. (1997). Defining and assessing intercultural competence: Some principles and proposals for the European context. Language Teaching, 29, 14-18.

Byram, M. (1997). Teaching and assessing intercultural communicative competence. Philadelphia, PA: Multilingual Matters.

CARLA. (The Center for Advanced Research on Language Acquisition). (1993-2006). Culture and language learning initiatives. Minnesota: University of Minnesota. Retrieved on July 4th, 2013, from http://www.carla.umn.edu/culture/initiati ves.html

Casmir, F. L. (1999). Foundations for the study of intercultural communication based on the third culture building model.International Journal of Intercultural Relations, 23, 91-116. 
Chen, G. M. (1989). Relationships of the dimensions of intercultural communication competence.Communication Quarterly, 37, 118-133.

Cloonan, A., Spencer, A., \& Saunders, S. (2005). Developing intercultural understanding: An introduction for teachers. Canberra: Department of Education, Science and Training.

Corbett, J. (2003). An intercultural approach to English language teaching. Clevedon: Multilingual Matters.

Creswell, J. W. (2007). Qualitative inquiry and research design: Choosing among five traditions $\left(2^{\text {nd }} e d.\right)$. Thousand Oaks, CA: Sage.

East, M. (2012). Addressing the intercultural via task-based language teaching: possibility or problem?, Language and Intercultural Communication, 12(1), 56-73.

Fantini, A. (2001). Exploring intercultural competence: A construct proposal. Paper presented at the 4th annual conference of NCOLCTL Fourth Annual Conference, April 2001, Las Vegas, USA.

Flinders Humanities Research Centre. (2005). Language and Intercultural Communication (LInC) group Discussion paper.

$\mathrm{Gu}$, X. (2016). Assessment of intercultural communicative competence in FL education: A survey on EFL teachers' perception and practice in China, Language and Intercultural Communication, 16(2), 254-273.

Han, X. (2003). Interpretation of religion psychology among contemporary adolescences. China Religion, 7, 34-35.
Huang, Y. (2014). Constructing intercultural communicative competence framework for English learners.Cross-Cultural Communication, 10(1), 97-101.

Liddicoat, A., Papademetre, L., Scarino, A., \& Kohler, M. (2003). Report on intercultural language learning. Canberra: Department of Education, Science and Training.

Lombard, C. N. (2014). Coping with anxiety and rebuilding identity: a psychosynthesis approach to culture shock. Counselling Psychology Quarterly, 27(2), 174-199.

Prechtl, E., \& Lund, D. (2007). Intercultural competence and assessment: Perspectives from the INCA project. Retrieved May, 12, 2012, from http://incaproject.org/

Rinehart, N. (2002). Utalitarian or idealist? Frameworks for assessing the study abroad experience. in Grünzweig, W., \& Rinehart, N. (Eds.), Rockin' in Red Square: critical approaches to international education in the age of cyber culture (7584). Münster: Lit Verlag.

Sehlaoui, A. S. (2001). Developing cross-cultural communicative competence in pre-service ESL/EFL teachers: A critical perspective. Language, Culture and Curriculum, 14(1), $42-57$.

Sinicrope, C., Norris, J., \& Watanabe, Y. (2007). Understanding and assessing intercultural competence: A summary of theory, research, and practice (technical report for the foreign language program evaluation project). Second Language Studies, 26(1), 1-58.

Song, L. (2008). Exploring a conceptual framework for intercultural communicative English language teaching in English. Shanghai International Studies University, unpublished. 
Tran, T. Q., \& Duong, T. M. (2018). The effectiveness of the intercultural language communicative teaching model for EFL learners. Asian-Pacific Journal of Second and Foreign Language Education, 3(6).

Wang, Q., Syhabuddin, Mulyati, Y., \& Damaianti, V. S. (2018). Perceiving and dealing with culture shock: the study of Chinese Indonesian-language students. International Journal of Education, 11(1), 20-28.

Wiseman, R. L. (2003). Intercultural communication competence.In W. B. Gudykunst (ed.), Cross cultural and intercultural communication (pp. 191208). Thousand Oaks, CA: Sage.
Yang, M., Webster, B., \& Prosser, M. (2011). Travelling a thousand miles: Hong Kong Chinese students' study abroad experience.International Journal of Intercultural Relations, 35(1), 69-78.

Zhang, H. (2007a). Intercultural approach to foreign language teaching (跨文化外语教 学). Shanghai: Shanghai Foreign Language Education Press. 